Asian-Australasian Journal of

Food Safety and Security

ISSN 2523-1073 (Print) 2523-2983(Online)

www.ebupress.com/journal/aajfss

\title{
Article \\ Interaction of variety and urea fertilizer and its impact on salt-tolerant Boro rice in the coastal area of Bangladesh
}

\author{
Kawsar Hossen ${ }^{1}$, Md. Imran Hossain Sohag ${ }^{1}$, Nusrat Jahan Sunny ${ }^{1}$, Md. Rayhan Sojib ${ }^{1}$, Tahmina Ferdous ${ }^{2}$, \\ Akhinur Shila ${ }^{3}$ and Rayhan Ahmed ${ }^{1 *}$ \\ ${ }^{1}$ Department of Agriculture, Noakhali Science and Technology University, Noakhali, Bangladesh \\ ${ }^{2}$ Department of Agricultural Economics, Bangabandhu Sheikh Mujibur Rahman Agricultural University, \\ Gazipur, Bangladesh \\ ${ }^{3}$ Department of Agricultural Botany, Patuakhali Science and Technology University, Patuakhali, Bangladesh \\ *Corresponding author: Rayhan Ahmed, Department of Agriculture, Faculty of Science, Noakhali Science and \\ Technology University, Noakhali-3814, Bangladesh. Phone: +8801717402875; E-mail: \\ rayhan.rimon@gmail.com
}

Received: 18 February 2020/Accepted: 12 April 2020/ Published: 30 May 2020

\begin{abstract}
Salt-tolerant Boro rice response under the interaction of variety and urea fertilizer was assessed in the southern coastal region of Bangladesh for developing coastal agriculture in Bangladesh. A field experiment was carried out at the research field of Agriculture department, Noakhali Science and Technology University (NSTU), Noakhali-3814 in a Randomized Complete Block Design (RCBD) with two varieties viz. BINA dhan8, BRRI dhan-67 and three doses of urea viz. $250 \mathrm{~kg} / \mathrm{ha}$., $150 \mathrm{~kg} / \mathrm{ha}$. and $120 \mathrm{~kg} / \mathrm{ha}$. were used as treatments where each treatment was replicated three times. Data were collected on plant height $(\mathrm{cm})$, tiller/hill, grain/panicle, 1000 grain weight $(\mathrm{g})$, grain yield ( $\mathrm{t} / \mathrm{ha}$.), straw yield ( $\mathrm{t} / \mathrm{ha}$.) and harvest index $(\%)$. All the parameters were influenced significantly by the interaction of variety and different doses of urea fertilizer and better performance was obtained from the variety BINA dhan- 8 and the doses of $250 \mathrm{~kg}$ urea/ ha. Finally, the present study suggests that for obtaining higher yield salt-tolerant BINA dhan-8 variety may be cultivated with $250 \mathrm{~kg}$ urea/ ha. in the southern coastal region of Bangladesh.
\end{abstract}

Keywords: Boro rice; coastal region; variety; urea; interaction

\section{Introduction}

Bangladesh is an agrarian country. About $76 \%$ of the total population of the country live in rural areas and $47.5 \%$ of the total manpower is involved in agriculture (BBS, 2016). Agriculture sector contributes more than $15 \%$ to the national GDP (Gross Domestic Product) of Bangladesh and 43\% of the total population get employment opportunities through agriculture sector. The rice sector alone contributes $50 \%$ of the agricultural GDP and 16.67\% of the national income in Bangladesh (BBS, 2018). In Bangladesh, rice is the most extensively cultivated cereal crop. It provides about $75 \%$ of the calories and $55 \%$ of the protein in the average daily diet of the people of our country (Bhuiyan et al., 2002). It also supplies nearly $48 \%$ of rural employment, about $2 / 3^{\text {rd }}$ of total calorie intake and about $50 \%$ of the total protein intake of an average person in the country (BBS, 2013). Bangladesh is one of the most important rice-growing countries of the world. Among the ricegrowing countries, Bangladesh occupies fourth position in rice production and third position in rice consumption in the world (FAOSTAT, 2012; FAPRI, 2009; BRRI, 2012). In order to obtaining food security in Bangladesh, one of the main way is to increasing rice production. In fact, 'Rice security' is the synonym of 'Food security' in Bangladesh (Brolley, 2015).

About $80 \%$ of total cropped area of this country is used for rice production with annual production of $4,37,29,000$ metric tons in total acreage of 1,10,59.000 ha. (IRRI, 2006). The annual cultivated area of rice is 
15.03 million hectares and the annual production about 38.34 million metric tons in Bangladesh (BBS, 2016). There are three rice growing seasons in Bangladesh named as Aus, Aman and Boro. Among them only Boro rice covers about $58 \%$ of total rice growing area and provides $56 \%$ of total food grain (BBS, 2015). Boro rice plays a vital role for food production and the economy of Bangladesh and hence, it can be considered as one of the most important rice crops for Bangladesh on the basis of high yield and contribution to rice production (Chamely et al., 2015).

About 30-50\% of net cropped area of Bangladesh remains fallow in Rabi and Kharif-1 season, mainly due to soil and water salinity. Introduction of new salt tolerant varieties in the fallow lands of the coastal regions might be the scholastic technique for improvement of system productivity (Ahmed et al., 2017). Besides, the population of our country is increasing and cultivable land area is decreasing every year mainly due to urbanization and industrialization. Therefore, attempts should be taken to increase the yield per unit area through use of comparatively high yielding varieties along with judicial fertilizer management (Salam et al., 2011; Janaiah et al., 2002).

Variety itself is a genetic factor which contributes a lot in producing yield and yield components of a particular crop. Yield components are directly related to the variety and neighboring environments in which it grows (Mikkelsen et al., 1995). Farmers can get (20-30) \% more yield per unit land area by using HYV (High Yielding Variety) of rice developed by BRRI (Bangladesh Rice Research Institute) instead of local indigenous low yielding rice varieties (Shahjahan, 2007).

Fertilizers have contributed substantially to the spectacular increase in the yield of rice. Among all nutrient elements, Nitrogen $(\mathrm{N})$ is the most important fertilizer element for the improvement of rice yield and the Nitrogen $(\mathrm{N})$ is frequently reported as deficient in agricultural soils of Bangladesh (Islam, 1990). Nitrogen fertilizer has positive influence on the production of effective tiller per plant, yield and yield attributes (Jashim et al., 1984; BRRI, 1990). On the other hand, deficiency of $\mathrm{N}$ decreases tillering, grain/ panicle and ultimately grain yield of rice (Peng et al., 2003). Therefore, optimum doses of $\mathrm{N}$ can play a vital role on the growth and development of rice plant (Hasanuzzaman et al., 2009). It is very important to identify the suitable doses of nitrogen (N) fertilizer for efficient management and better yield of rice. Significantly highest yield of rice was recorded between ranges of 90-250 kg/ ha. (Marazi et al., 1993; Daniel and Wahab, 1994; Bali et al., 1995; Meena et al., 2003).

A suitable combination of variety and rate of Nitrogen (N) is necessary for better yield of rice (BRRI, 1990). Considering the above discussions, the present study was undertaken to observe the varietal performance of Boro rice, to find out the effect of Nitrogen $(\mathrm{N})$ fertilizer on the yield of Boro rice and for assessing the interactive effect of variety and Nitrogen $(\mathrm{N})$ fertilizer in the coastal region of Bangladesh.

\section{Materials and Methods}

\subsection{Time and location}

The experiment was conducted at the research field of Agriculture department, Noakhali Science and Technology University (NSTU), Noakhali-3814 from November 2018 to May 2019. The experimental field is under the agro-ecological region of the Young Meghna Estuarine Floodplain (AEZ-18). The land was almost level having sandy loam soil and moderately alkaline (SRDI, Noakhali), with pH value 7.5 and electrical conductivity $0.91 \mathrm{dS} / \mathrm{m}$. A pH Meter (Hach sensION+ PH1 Basic Portable pH Meter) and an EC meter (sensION+ EC7) were used to measure $\mathrm{pH}$ and electrical conductivity respectively. The experimental area is under the tropical climate with an average annual temperature of $25.6{ }^{\circ} \mathrm{C}$ and the average annual rainfall about 3,302 mm (Weather Station, Maizdee, Noakhali).

\subsection{Experimental design}

Two factors included in the experiment were as follows: Factor A: Variety (2); $\mathrm{V}_{1}-$ BINA dhan-8, $\mathrm{V}_{2}$ - BRRI dhan-67 and Factor B: Treatments (3); $\mathrm{T}_{1}-250 \mathrm{~kg}$ Urea/ ha, $\mathrm{T}_{2}-150 \mathrm{~kg}$ Urea/ ha, $\mathrm{T}_{3}-120 \mathrm{~kg}$ Urea/ ha. Seeds of BINA dhan-8 were collected from Bangladesh Institute of Nuclear Agriculture (BINA), Mymensingh-2202 and BRRI dhan-67 were collected from Bangladesh Rice Research Institute (BRRI), Gazipur, Bangladesh. The experiment was laid out in a Randomized Complete Block Design (RCBD) with three replications. The size of each unit plot was $3.0 \mathrm{~m} \times 2.0 \mathrm{~m}$, having an area of $6 \mathrm{~m}^{2}$. So, the total number of the unit plot was $18(3 \times 3 \times 2)$. A spacing of $50 \mathrm{~cm}$ and $80 \mathrm{~cm}$ was maintained between the replications and unit plot respectively.

\subsection{Seedlings establishment}

The seeds were soaked in the water for 24 hours and then were taken out of the water, covered with wet gunny bags and then kept for sprouting. After 48 hours' seeds were started sprouting and almost all seeds were 
sprouted after 72 hours. Pre-germinated seeds of the two variety were broadcasted uniformly in a well-prepared nursery bed on 16 December 2018.

\subsection{Final land preparation}

Plowing and cross-plowing was done by a tractor to prepare the land and subsequently laddering to level the land. The field was fertilized with Triple Super Phosphate (TSP), Muriate of Potash (MoP) and Gypsum at the rate of $120 \mathrm{~kg}, 80 \mathrm{~kg}$ and $60 \mathrm{~kg}$ per hector respectively during land preparation. Urea was applied (as per treatment) as top dressing in three equal splits at 15, 30 and 45 days after transplanting (DAT).

\subsection{Seedlings transplanting}

Before uprooting the seedlings, nursery bed was slightly irrigated for easier uprooting. Uprooting of seedlings were done carefully from the nursery bed and were transplanted in the unit plots on 25 January 2019 where spacing was maintained at $25 \mathrm{~cm} \times 15 \mathrm{~cm}$ (row to row and plant to plant) at the rate of 1-2 seedlings/hill. Hand weeding was done at 20 and 35 days after transplanting (DAT). The field was irrigated from the nearest water source (pond) by irrigation devices when necessary. A regular observation was made to ensure better growth of plants.

\subsection{Collection and analysis of data}

Randomly ten hills (excluding border hills) were selected from each unit plot and uprooted before harvesting for data collection. The harvested crop of each unit plot was bundled separately, tagged properly, brought to the threshing floor and then threshed by a pedal thrasher. Grain and straw were sun-dried at $14 \%$ moisture level and cleaned. Data were collected on plant height $(\mathrm{cm})$, tillers/hill, grain/panicle, 1000 grain weight $(\mathrm{g})$, grain yield (t/ha), straw yield (t/ha) and harvest index (\%). Plant height (selected ten plants) was measured from the base to the tip of the longest panicle. Tiller comprising at least one visible leaf were counted. Spikelet that contain any food material was considered as grain and the number of grain in each panicle was counted. One thousand clean dried seed from the seed lot of each unit plot were counted separately and weight by an electrical balance. The recorded grain and straw yield per plot was finally converted to t/ha. Harvest index (\%) was calculated with the following formula. Harvest index $(\%)=($ Grain yield $\div$ Biological yield $) \times 100$

Where, Biological yield $=$ Grain yield + Straw yield.

Data recorded for growth, yield and yield contributing characters were compiled and tabulated in proper form for statistical analysis. Analysis of variance was done with the help of MSTAT-C computer package program developed by Russel (1986). The mean differences among the treatments were adjudged by DMRT test (Gomez, 1984).

\section{Results and Discussion}

\subsection{Impact of variety on the yield and yield component of salt-tolerant Boro rice}

Variety had a non-significant effect on yield and yield attributes of Boro rice (Table 1).

The highest plant height $(95.36 \mathrm{~cm})$ was observed in BINA dhan-8 compared with BRRI dhan-67 $(85.57 \mathrm{~cm})$ and this result is consistent with some other researcher (Sarker et al., 2013; Shel et al., 2015; Islam et al., 2015; Alam et al., 2012). Khisha (2002) also found the highest plant height (129.94 cm) in BINA dhan-5, which is higher than those of Sonar Bangla-1 and BRRI dhan-29.

BRRI dhan-67 produced more tiller/hill (18.12) than BINA dhan-8 (13.22) which is similar with the findings of other researcher (Islam et al., 2015; Tyeb et al., 2013; Sarker et al., 2013). BINA (1998) conducted a field trial during the Boro season of 1997-98 and found that the hybrid rice Alok-6201 gives higher number of tiller/hill than the modern variety IRATOM-24.

Highest number of grain/ panicle was found in BINA dhan-8 (131.08) in comparison with BRRI dhan-67 (107.9). Tyeb et al. (2013) reported that variety BRRI dhan-52 produced more number of grain/ panicle than other varieties. Hasan et al. (2002) also observed highest number of grain/ panicle in BRRI dhan-34 than Alok6201 .

Thousand grain weight (g) was found maximum in BRRI dhan-67 (31.42) than BINA dhan-8 (22.55). Islam et al. (2015) found the higher 1000-grain weight (25.49 g) in BR-11 and the lower one (21.33 g) in BRRI dhan-49. BINA dhan-8 and BRRI dhan-67 showed less variation in grain yield ( $\mathrm{t} / \mathrm{ha})$ and straw yield (t/ha). BINA dhan- 8 gave highest grain yield (7.24) and straw yield (7.6) than BRRI dhan-67. Sultana et al., (2012) also found highest harvest yield in BRRI dhan-51 compared to BR-11 and BRRI Dhan-52. Similarly, Rajaul (2005) observed the highest straw yield (5.54 t/ha) in BRRI dhan-29 and lowest $(5.43 \mathrm{t} / \mathrm{ha})$ in BRRI dhan-28 that supports our result. 
More or less similar result obtained from BINA dhan-8 and BRRI dhan-67 for harvest index (\%). Among the varieties BRRI dhan-67 (48.87) showed slightly higher result than BINA dhan-8 (48.79). Arshad (2009) reported that the highest harvest index (41.9\%) was obtained by BRRI dhan-40 and the lowest one (40.08\%) was obtained from BRRI dhan-41.

\subsection{Impact of urea fertilizer on the yield and yield component of salt-tolerant Boro rice}

Different doses of urea fertilizer had a non-significant effect on yield and yield contributing characters of Boro rice (Table 2).

Non-significant differences observed for plant height $(\mathrm{cm})$ among different treatments. Here highest plant height found from $\mathrm{T}_{1}$ (93) and lowest from $\mathrm{T}_{3}$ (85.8) which indicates increasing rate of urea increased plant height. Islam et al. (2008) conducted an experiment with 40,60,80, 100 and $120 \mathrm{~kg} \mathrm{~N} / \mathrm{ha}$. on BRRI dhan-33 and observed that increasing rate of $\mathrm{N}$ increased plant height which is consistent with our result and some other research findings (Prakash et al., 2014; Shekara et al., 2010; Ahmed et al., 2005; Zhilin et al., 1997; Sendra et al., 1993).

Similar with plant height, number of tiller/ hill increased slightly with the increasing of urea fertilizer. Maximum number of tiller/ hill was observed at $T_{1}$ (12.61) and minimum at $T_{3}$ (11.26). Similar results also found from some other researcher (Shekara et al., 2010; Chander and Pandey, 1996).

On the contrary, number of grain/ panicle decreased with the increasing rate of urea fertilizer. Here, highest number of grain /panicle observed from $T_{3}$ (123.35) and lowest from $T_{1}$ (116.65). Rajarathinam and Balasubramaniyan (1999) also noticed an appreciable reduction in grain/ panicle at $250 \mathrm{~kg} \mathrm{~N} / \mathrm{ha}$. which is similar with our result as well as Yosida and Parao (1976).

Similarly, 1000 grain weight $(\mathrm{g})$ also reduced with the increasing rate of Urea fertilizer. The maximum 1000 grain weight found from $120 \mathrm{~kg}$ urea/ ha. (31) and lowest from $250 \mathrm{~kg}$ urea/ ha. (24.66) which is consistent with the result of Azam et al. (2009). He reported that the highest 1000-grain weight ( $24.70 \mathrm{~g})$ obtained at $55 \mathrm{~kg} \mathrm{~N} /$ ha. and lowest $(24.09 \mathrm{~g}) 1000$-grain weight observed at $110 \mathrm{~kg} \mathrm{~N} / \mathrm{ha}$.

Highest Grain yield $(\mathrm{t} / \mathrm{h})$ and Straw yield $(\mathrm{t} / \mathrm{h})$ was found from $250 \mathrm{~kg}$ urea/ ha. (7.45 and 7.92 respectively) and lowest from $120 \mathrm{~kg}$ urea/ ha. (5.51 and 6.48 respectively) and a decreasing trend also found with the increase of rea fertilizer. Maqsood et al. (1997) carried out an experiment at Faisalabad during 1994 and 1995 on rice cv. Basmati-385 by applying 0-100 kg N/ ha. and found that yield increased with increasing $\mathrm{N}$ rate in both the years. BRRI (1995) conducted several experiments at different stations on BR-11 and BR-14 and reported that application of $100 \mathrm{~kg} \mathrm{~N} /$ ha. increased straw yields of rice. However, from many investigations BRRI (1995) revealed that straw yield is strongly influenced by nitrogen fertilization.

Harvest index (\%) increased with the increase of rea application up to $150 \mathrm{~kg}$ rea/ ha. and then decreased with the increase of rea application. Sarker et al. (2001) observed that application of nitrogen increased harvest index up to $120 \mathrm{~kg} \mathrm{~N} /$ ha.

\subsection{Interactive effect of variety and urea fertilizer on the yield and yield component of salt-tolerant Boro rice}

The interactive effect of variety and urea had significant influence on yield and yield contributing characters of salt-tolerant Boro rice excluding number of tiller/ hill and number of grain/ panicle (Table 3).

Plant height $(\mathrm{cm})$ significantly influenced by the interaction effect of variety and urea. The highest plant height (98.63) observed at $\mathrm{V}_{1} \mathrm{~T}_{1}$ combination (BINA dhan-8 and $250 \mathrm{~kg}$ urea/ ha.), on the other hand lowest (81.26) at $\mathrm{V}_{2} \mathrm{~T}_{3}$ combination (BRRI dhan-67 and $120 \mathrm{~kg}$ urea/ ha.).

The interactive effect of variety and urea on number of tiller/ hill was found non-significant. Same as plant height, maximum number of tiller/ hill (15.13) found from the combination of $\mathrm{V}_{1} \mathrm{~T}_{1}$ (BINA dhan-8 and $250 \mathrm{~kg}$ urea/ ha.) and minimum number of tiller/ hill (9.40) from $\mathrm{V}_{2} \mathrm{~T}_{3}$ (BRRI dhan-67 and $120 \mathrm{~kg}$ urea/ ha.).

Non-significant interactive effect also found on grain/ panicle. In case of grain/ panicle, highest value (136.23) obtained from $\mathrm{V}_{1} \mathrm{~T}_{3}$ (BINA dhan-8 and $120 \mathrm{~kg}$ urea/ ha.) and the lowest (105.53) from $\mathrm{V}_{2} \mathrm{~T}_{1}$ (BRRI dhan-67 and $250 \mathrm{~kg}$ urea/ ha.).

1000 grain weight $(\mathrm{g})$ varied significantly by the interaction of variety and Urea fertilizer. Maximum weight of thousand grain (30.27) observed at the combination of $\mathrm{V}_{2} \mathrm{~T}_{3}$ (BRRI dhan-67 and $120 \mathrm{~kg}$ urea/ ha.) and the minimum weight of thousand grain (19.20) obtained from $\mathrm{V}_{1} \mathrm{~T}_{1}$ (BINA dhan-8 and $250 \mathrm{~kg}$ urea/ ha.).

Grain yield and straw yield ( $t /$ ha.) significantly influenced by the interactive effect of variety and urea. Highest grain yield and straw yield (8.05 and 8.95 respectively) gained from $\mathrm{V}_{1} \mathrm{~T}_{1}$ combination (BINA dhan-8 and 250 $\mathrm{kg}$ urea/ ha.) and lowest (5.08 and 5.73 respectively) gained from $\mathrm{V}_{2} \mathrm{~T}_{3}$ combination (BRRI dhan-67 and $120 \mathrm{~kg}$ urea/ ha.). 
Harvest index (\%) also affected significantly by the interaction of variety and urea fertilizer. Highest value (52.34) obtained from the combination of $\mathrm{V}_{2} \mathrm{~T}_{1}$ (BRRI dhan-67 and $250 \mathrm{~kg}$ urea/ ha.) and lowest value (47.2) obtained from $\mathrm{V}_{1} \mathrm{~T}_{1}$ (BINA dhan-8 and $250 \mathrm{~kg}$ urea/ ha.).

Table 1. Impact of variety on the yield and yield component of salt-tolerant Boro rice.

\begin{tabular}{|l|l|l|l|l|l|l|l|}
\hline Variety & $\begin{array}{l}\text { Plant } \\
\text { height }(\mathbf{c m})\end{array}$ & $\begin{array}{l}\text { Tiller/ } \\
\text { hill }\end{array}$ & $\begin{array}{l}\text { Grain/ } \\
\text { panicle }\end{array}$ & $\begin{array}{l}\text { 1000 grain } \\
\text { weight }(\mathbf{g})\end{array}$ & $\begin{array}{l}\text { Grain yield } \\
(\mathbf{t} / \text { ha) }\end{array}$ & $\begin{array}{l}\text { Straw yield } \\
(\mathbf{t} / \mathbf{h a})\end{array}$ & $\begin{array}{l}\text { Harvest } \\
\text { index }(\boldsymbol{\%})\end{array}$ \\
\hline BINA dhan-8 & 95.36 & 13.22 & 131.08 & 22.55 & 7.24 & 7.6 & 48.79 \\
\hline BRRI dhan-67 & 85.57 & 18.12 & 107.9 & 31.42 & 6.06 & 6.34 & 48.87 \\
\hline Mean & 90.47 & 15.67 & 119.49 & 26.99 & 6.65 & 6.97 & 48.83 \\
\hline std & 6.92 & 3.46 & 16.39 & 6.27 & 0.83 & 0.89 & 0.06 \\
\hline Cv (\%) & 7.65 & 22.11 & 13.72 & 23.24 & 12.55 & 12.78 & 0.12 \\
\hline $\begin{array}{l}\text { Level of } \\
\text { significance }\end{array}$ & NS & NS & NS & NS & NS & NS & NS \\
\hline
\end{tabular}

Table 2. Impact of different doses of urea fertilizer on the yield and yield component of salt-tolerant Boro rice.

\begin{tabular}{|l|l|l|l|l|l|l|l|}
\hline Treatment & $\begin{array}{l}\text { Plant height } \\
(\mathbf{c m})\end{array}$ & $\begin{array}{l}\text { Tiller/ } \\
\text { hill }\end{array}$ & $\begin{array}{l}\text { Grain/ } \\
\text { panicle }\end{array}$ & $\begin{array}{l}\mathbf{1 0 0 0} \text { grain } \\
\text { weight }(\mathbf{g})\end{array}$ & $\begin{array}{l}\text { Grain } \\
\text { yield (t/h) }\end{array}$ & $\begin{array}{l}\text { Straw } \\
\text { yield }(\mathbf{t} / \mathbf{h})\end{array}$ & $\begin{array}{l}\text { Harvest } \\
\text { index }(\%)\end{array}$ \\
\hline $\mathrm{T}_{1}(250 \mathrm{~kg}$ Urea/ ha. $)$ & 93 & 12.61 & 116.65 & 24.66 & 7.45 & 7.92 & 48.47 \\
\hline $\mathrm{T}_{2}(150 \mathrm{~kg}$ Urea/ ha. $)$ & 92.6 & 12.03 & 118.5 & 25.3 & 6.88 & 7.02 & 49.5 \\
\hline $\mathrm{T}_{3}(120 \mathrm{~kg}$ Urea/ ha. $)$ & 85.8 & 11.26 & 123.35 & 31 & 5.51 & 6.48 & 45.95 \\
\hline Mean & 90.47 & 11.97 & 119.50 & 26.99 & 6.61 & 7.14 & 47.97 \\
\hline std & 4.05 & 0.68 & 3.46 & 3.49 & 1.00 & 0.73 & 1.83 \\
\hline cv & 4.47 & 5.66 & 2.90 & 12.93 & 15.08 & 10.19 & 3.81 \\
\hline $\begin{array}{l}\text { Level of } \\
\text { significance }\end{array}$ & $\mathrm{NS}$ & $\mathrm{NS}$ & $\mathrm{NS}$ & $\mathrm{NS}$ & $\mathrm{NS}$ & $\mathrm{NS}$ & NS \\
\hline
\end{tabular}

Table 3. Interactive effect of variety and Urea fertilizer on the yield and yield component of salt-tolerant Boro rice.

\begin{tabular}{|l|l|l|l|l|l|l|l|}
\hline Treatment & $\begin{array}{l}\text { Plant height } \\
(\mathbf{c m})\end{array}$ & $\begin{array}{l}\text { Tiller/ } \\
\text { hill }\end{array}$ & $\begin{array}{l}\text { Grain/ } \\
\text { panicle }\end{array}$ & $\begin{array}{l}\text { 1000 grain } \\
\text { weight }(\mathbf{g})\end{array}$ & $\begin{array}{l}\text { Grain yield } \\
(\mathbf{t} / \mathbf{h a})\end{array}$ & $\begin{array}{l}\text { Straw } \\
\text { Yield }(\mathbf{t} / \mathbf{h a})\end{array}$ & $\begin{array}{l}\text { Harvest } \\
\text { index }(\%)\end{array}$ \\
\hline $\mathrm{V}_{1} \mathrm{~T}_{1}$ & 98.63 & 15.13 & 128.75 & 19.20 & 8.05 & 8.95 & 47.25 \\
\hline $\mathrm{V}_{1} \mathrm{~T}_{2}$ & 95.43 & 14.90 & 130.30 & 21.47 & 6.93 & 7.22 & 48.02 \\
\hline $\mathrm{V}_{1} \mathrm{~T}_{3}$ & 89.23 & 12.03 & 136.23 & 22.83 & 6.0 & 6.17 & 48.34 \\
\hline $\mathrm{V}_{2} \mathrm{~T}_{1}$ & 90.77 & 11.60 & 105.53 & 26.17 & 6.47 & 6.93 & 52.34 \\
\hline $\mathrm{V}_{2} \mathrm{~T}_{2}$ & 85.57 & 10.17 & 106.40 & 29.93 & 6.17 & 6.03 & 51.24 \\
\hline $\mathrm{V}_{2} \mathrm{~T}_{3}$ & 81.26 & 9.40 & 108.47 & 30.27 & 5.08 & 5.73 & 48.52 \\
\hline Mean & 90.15 & 12.21 & 119.28 & 24.98 & 6.45 & 6.84 & 49.29 \\
\hline std & 6.34 & 2.38 & 13.93 & 4.57 & 0.99 & 1.18 & 2.02 \\
\hline $\mathrm{CV}(\%)$ & 7.03 & 19.47 & 11.68 & 18.28 & 15.42 & 17.23 & 4.10 \\
\hline $\begin{array}{l}\text { Level of } \\
\text { significance }\end{array}$ & $* *$ & $\mathrm{NS}$ & $* * *$ & $* * *$ & $* * *$ & $* * *$ \\
\hline
\end{tabular}

NS = Non Significant; ${ }^{* * *}=$ Significant at $0.1 \%$ level of probability; ${ }^{* *}=$ Significant at $1 \%$ level of probability;

* = Significant at $5 \%$ level of probability

\section{Conclusions}

Results showed that, the performance of BINA dhan- 8 was better than BRRI dhan-67 in terms of plant growth, grain yield and straw yield. Similarly, among the different doses of urea fertilizer, highest yield obtained from $250 \mathrm{~kg}$ urea/ ha. Finally, it can be concluded that, the interaction of BINA dhan- 8 and $250 \mathrm{~kg} \mathrm{urea} / \mathrm{ha} .\left(\mathrm{V}_{1} \mathrm{~T}_{1}\right)$ was the best combination to obtain higher yield in the southern coastal region of Bangladesh. However, this approach needs to be tested in different coastal region of Bangladesh before making final inference.

\section{Conflict of interest}

None to declare. 


\section{References}

Ahmed M, MM Islam, SK Paul and B Khulna, 2005. Effect of nitrogen on yield and other plant characters of Local T. aman Rice, Var. Jatai. Res. J. Agric. \& Biol. Sci., 1: 158-161.

Ahmed R, MHK Howlader, A Shila and MA Haque, 2017. Effect of salinity on germination and early seedling growth of maize. Progressive Agriculture, 28: 18-25.

Alam MS, MA Baki, MS Sultana, KJ Ali and MS Islam, 2012. Effect of variety, spacing and number of seedlings per hill on the yield potentials of transplant aman rice. Int. J. Agr. \& Agri., 2: 10-15.

Arshad HM, 2009. Effect of cultivar and planting method on the performance of transplant aman rice. MS thesis, Department of Agronomy, Bangladesh Agricultural University, Mymensingh. pp. 39.

Azam SMG, 2009. Evaluation of urea supergranule as a source of nitrogen in transplant aman rice. MS Thesis, Department of Agronomy, Faculty of Agriculture, Bangladesh Agricultural University, Mymensingh-2202. pp. 28-41.

Bali AS, M Siddique, BA Ganai, HV Khan and KN Singh, 1995. Response of rice (Oryza sativa) genotypes to nitrogen levels under transplanted conditions in Kashmir valley. Indian J. Agron., 40: 35-37.

BBS, 2013. Statistical Year Book of Bangladesh. Bangladesh Bureau of Statistics, Statistics Division, Ministry of Planning, Government People's Republic of Bangladesh, Dhaka. pp. 189-258.

BBS, 2015. Statistical Year Book of Bangladesh. Bangladesh Bureau of Statistics, Statistics Division, Ministry of Planning, Government People's Republic of Bangladesh, Dhaka.

BBS, 2016. Statistical Year Book of Bangladesh. Bangladesh Bureau of Statistics, Statistics Division, Ministry of Planning, Government People's Republic of Bangladesh, Dhaka.

BBS, 2018. Statistical Year Book of Bangladesh. Bangladesh Bureau of Statistics, Statistics Division, Ministry of Planning, Government People's Republic of Bangladesh, Dhaka.

Bhuiyan MSU, SMA Hossain and SKG Kabir, 2002. Nitrogen fertilization in rice cv. BR10 after green manuring. Bangladesh J. Agril. Sci., 16: 89-92.

BINA, 1998. Technical report on hybrid rice Alok 6201. Division of Agronomy, Bangladesh Institute of Nuclear Agriculture, Mymensingh-2202. pp. 1-3.

Brolley M, 2015. Rice security is food security for much of the world. Rice Today. International Rice Research Institute (IRRI), DAPO Box 7777, Metro Manila, Philippines. pp. 30-32.

BRRI (Bangladesh Rice Research Institute), 1995. Annual Report for 2005-2006. Bangladesh Rice Res. Inst, Joydebpur, Gazipur, Bangladesh. pp. 33-39.

BRRI, 1990. Nitrogen response of promising variety. Annual Report of Bangladesh Rice Research Institute, Joydebpur, Gazipur, pp. 95.

BRRI, 2012. Annual Report for 2011. Bangladesh Rice Research Institute, Joydebpur, Gazipur, Bangladesh, pp. 9-13.

Chamely SG, N Islam, S Hoshain, MG Rabbani, MA Kader and MA Salam, 2015. Effect of variety and nitrogen rate on the yield performance of boro rice. Progressive Agriculture, 26: 6-14.

Chander S and J Pandey, 1996. Effect of herbicide and nitrogen on yield of scented rice (Oryza sativa) under different rice cultures. Indian J. of Agron., 41: 209-214.

Daniel KV and K Wahab, 1994. Levels and time of nitrogen in semi dry rice. Madras Agric. J., 81: 357-358.

FAOSTAT, 2012. Food and Agricultural Commodities Production 2010. Food and Agriculture Organization of the United Nations. Available at http://faostat. fao.org/site/339/default.aspx.

FAPRI, 2009. The Agricultural Outlook 2009. World Rice. Food and Agricultural Policy Research Institute. Available at http://www.fapri. iastate. edu/outlook/2009/.

Gomez KA and AA Gomez, 1984. Ducan's Multiple Range Test. Statistical Procedures for Agricultural Research. 2nd Edn., A wiley Inter-Science Publication, Jhon Wiley and Sons, New York. pp. 202-215.

Hasan MS, SMA Hossain, M Salim, MP Anwar and AKM Azad, 2002. Response of hybrid and inbred rice varieties to the application methods of urea super granules and prilled urea. Pakistan J. Bio. Sci., 5: 746-748.

Hasanuzzaman M, K Nahar, MM Alam, MZ Hossain and MR Islam, 2009. Response of transplanted rice to different application methods of urea fertilizer. Intl. J. Sust. Agric., 1: 01-05.

IRRI, 2006. World Rice Statistics. International Rice Research Institute http://www.irri.org/science/wrs. Accessed on July, 2007.

Islam A, J Chandrabiswas, AJMS Karim, M Salmapervin and MA Saleque, 2015. Effects of Potassium Fertilization on Growth and Yield of Wetland Rice in Grey Terrace Soils of Bangladesh. Research on Crop Ecophysiology J., 10: 64-82.

Islam MS, 1990. Nutrient status of some soils of Bangladesh. In: Proceeding of International symposium on paddy soil fertility. Bangladesh Agricultural Research Council, Dhaka, Bangladesh. pp. 23-43. 
Islam MS, MM Akhter, MS Rahman, MB Banu and KM Khalequzzaman, 2008. Effect of nitrogen and number of seedlings per hill on the yield and yield components of T. aman rice (BRRI dhan33). Int. J. Sustainable Crop Prod., 3: 61-65.

Janaiah A, M Hossain and M Husain, 2002. Hybrid Rice for Tomorrow's Food Security: Can the Chinese Miracle be Replicated in other Countries? Outlook Agric., 31: 23-33.

Jashim C, U Ahmed and KU Ahmed, 1984. Response of rice varieties to applied N in saline soils. Intl. Rice Res. Newsl., 9: 22.

Khisha K, 2002. An Evaluating of Madagascar System of Rice Production in Aman Season with Three High Potential Rice Varieties. MS Thesis, Department of Agronomy, Faculty of Agriculture, Bangladesh Agricultural University, Mymensingh-2202. pp. 98.

Maqsood M, A Hussain, SA wajid and N Akbar, 1997. Effects of planting methods and variable rates of nitrogen application on yield and component of yield of rice. Pakistan J. Agril. Sci., 34: 89-93.

Marazi AR, GM Khan, KH Singh and AS Bali, 1993. Response of rice (Oryza sativa) to different N levels and water regimes in Kashmir Valley. Indian J. Agric. Sci., 63: 726-727.

Meena SL, S Surendra, YS Shivay and S Singh, 2003. Response of hybrid rice (Oryza sativa) to nitrogen and potassium application in sandy clay loam soils. Indian J. Agric. Sci., 73: 8-11.

Mikkelsen D, GR Jayaweera and DE Rolston, 1995. Nitrogen fertilization practices of lowland rice culture. Nitrogen fertilization in the environment, 171.

Peng S, R Buresh, J Huang, J Yang, G Wang, X Zhong and Y Zou, 2003. Principles and practices of real time nitrogen management: a care study on irrigated rice in China. Rice Science: Innovations and Impact for Livelihood. International Rice Research Institution, Los Banos, Philippines, pp. 433.

Prakash C, NR Koli, RK Shivran, JC Sharma and R Kumar, 2014. Response of nitrogen levels and weed management practices on productivity of rice (Oryza sativa L.) under aerobic condition. BIOINFOLET- A Quarterly Journal of Life Sciences, 11: 145-148.

Rajarathinam P and P Balasubramaniyan, 1999. Effect of plant population and nitrogen on yield attributes and yield of hybrid rice. Indian J. Agron., 44: 717-721.

Rajaul KM, 2005. Effect of weeding regime and variety on the yield components of boro rice. MS thesis, Department of Agronomy, Faculty of Agriculture, Bangladesh Agricultural University, Mymensingh-2202. pp. 43.

Russel DF, 1986. MSTAT-C package programme. Crop and Soil Science Department, Michigan State University, USA. Gomez KA and AA Gomez, 1984. Statistical procedure for agricultural research. 2nd ed. John Wiley and Sons. New York. pp. 64.

Salam MA, F Lucy, MH Kabir and AR Khan, 2011. Effect of different doses of fertilizers on yield and yield components of two varieties of boro rice. J. Agrofor. Environ., 5: 53-56.

Sarkar ABS, N Kojims and Y Amano, 2001. Effect of Nitrogen rates on japonica and indica rice under irrigated ecosystem. Bangladesh J. Sci. and tech., 3: 49-58.

Sarker BC, M Zahan, UK Majumder, MA Islam and B Roy, 2013. Growth and yield potential of some local and high yielding boro rice varieties. J. Agrofor. Environ., 7: 107-110.

Sendra J, R Carreres and F Tarazona, 1993. Effect of nitrogen, phosphorus and potassium fertilizer on yield of rice. India J. Agron., 8: 221-234.

Shahjahan M, 2007. Modern rice in Asia: Role in food security and poverty alleviation. Financial Express. pp. 1589.

Shekara BG and D Shreedhara, 2010. Growth and yield of aerobic rice (Oryza sativa L.) as influenced by different levels of NPK in cauvery command area. J. Maharashtra Agric. Univ., 35: 195-198.

Shel SK, 2015. Effect of row spacing on growth and yield of short duration transplant aman rice varieties. MS thesis, Department of Agronomy, Faculty of Agriculture, Bangladesh Agricultural University, Mymensingh2202. 22-28.

Sultana M, MA Kader, MS Islam and F Zaman, 2012. Performance of transplanted aman rice under various levels and sources of nitrogen application. Bangladesh J. Environ. Sci., 23: 202-206.

Tyeb A, SK Paul and MA Samad, 2013. Performance of variety and spacing on the yield and yield contributing characters of transplanted aman rice. J. Agrofor. Environ., 7: 57-60.

Yoshida S and FT Parao, 1976. Climatic influence on yield and yield components of lowland rice in the tropics. Climate and Rice, Los Banos, Philippines. pp. 471-494.

Zhilin L, RS Sarkar, SK Nayak and I Ravi. 1999. Physiological effect of nitrogen application on aromatic rice. J. South China Agric. Univ., 3. 